\title{
Hubungan Kepribadian Big Five Terhadap Pembentukan Organizational Citizenship Behaviour (OCB) Pegawai Pada PT Amarta Karya (Persero) Bekasi
}

\author{
Salwa ${ }^{1)^{*}}$, Rinandita Wikansari ${ }^{2)}$ \\ Program Studi Manajemen Sumber Daya Manusia, Politeknik APP Jakarta, Indonesia \\ Kementerian Perindustrian Republik Indonesia, Jl. Timbul 34 Cipedak Jagakarsa Jakarta Selatan \\ *Email: salwawawa32@gmail.com
}

\begin{tabular}{|c|c|}
\hline Article Info & ABSTRAK \\
\hline $\begin{array}{l}\text { Received: } \\
29 \text { Agustus } 2017 \\
\text { Revised: } \\
23 \text { September } 2017 \\
\text { Accepted: } \\
27 \text { Oktober } 2017\end{array}$ & $\begin{array}{l}\text { Penelitian ini bertujuan untuk membuktikan hubungan kepribadian Big Five } \\
\text { Personality terhadap pembentukan Organizational Citizenship Behaviour (OCB) } \\
\text { pegawai pada PT Amarta Karya (persero) Bekasi. Penelitian ini menggunakan metode } \\
\text { kuantitatif. Alat ukur yang digunakan dalam penelitian ini adalah kuesioner yang } \\
\text { terbagi menjadi } 2 \text { skala yaitu, skala kepribadian terdiri dari } 35 \text { butir pernyataan dan }\end{array}$ \\
\hline & $\begin{array}{l}\text { skala OCB yang terdiri dari } 20 \text { butir pernyataan. Jumlah responden pada penelitian ini } \\
\text { sebanyak } 30 \text { orang. Teknik analisis data yang digunakan dalam penelitian ini adalah } \\
\text { menggunakan analisis korelasi Product Moment Pearson dengan bantuan aplikasi } \\
\text { SPSS } 2.0 \text { dalam perhitungannya. Hasil penelitian menunjukan di antara } 5 \text { dimensi } \\
\text { kepribadian ditemukan bahwa Openness merupakan dimensi kepribadian yang secara } \\
\text { signifikan memiliki hubungan terhadap pembentukan OCB karyawan PT Amarta Karya } \\
\text { (persero) Bekasi. Terdapat hubungan ang signifikan variabel openness sebesar 0,377 } \\
\text { dengan signifikansi 0,040 < 0,05 terhadap pembentukan OCB karyawan PT Amarta } \\
\text { Karya (persero. }\end{array}$ \\
\hline
\end{tabular}

Kata Kunci: Organizational Citizenship Behaviour (OCB), Big Five Personality

\section{The relationship of big five personality on the formation employee organizational citizenship behavior (OCB) at PT Amarta Karya (Persero) Bekasi}

\begin{abstract}
This research aimed to determine the relation the Big Five Personality Dimension to Organizational Citizenship Behavior (OCB) employees of PT Amarta Karya (Persero) Bekasi..This Research used quantitative method. The measuring tool used in this research is a questionnaire divided into 2 scales those are, the personality scale consists of 35 points statements and OCB scale consists of 20 items statemenst. The number of respondents in this research is 30 employee. This research used product moment pearson correlation as a data analysis technique and used SPSS 2.0 Application as a tool to calculate data. The results showed that among 5 personality dimensions found that Openness is a personality dimension that significantly has a relation with the employee's OCB of PT Amarta Karya (Persero) Bekasi. There is a significant relation of openness variable 0,377 with significance $0,040<0,05$ to employee's OCB of PT Amarta Karya (Persero) Bekasi.
\end{abstract}

Keywords : Organizational Citizenship Behaviour(OCB), Big Five Personality

Salwa., dan Wikansari, R. (2017). Hubungan Big Five Personality Terhadap Pembentukan Organizational Citizenship Behaviour (Ocb) Pegawai Pada PT Amarta Karya (Persero) Bekasi. Jurnal Ilmiah Manajemen \& Bisnis, 18(2), 164176. 


\section{PENDAHULUAN}

Pegawai sebagai sumber daya manusia dipandang sebagai asset yang penting dalam suatu perusahaan. Pegawai yang berkualitas dan kompetitif akan menghasilkan tingkat kinerja yang baik. Tingkat kinerja yang baik dapat diwujudkan dengan membentuk perilaku extra role pegawai. yaitu perilaku dimana pegawai melakukan pekerjaan yang secara formal bukan syarat dari pekerjaannya. Perilaku ini dikenal sebagai Organizatonal Citizenship Behaviour atau dapat disingkat OCB. (Sari \& Hajriani, 2015)

Perilaku OCB ini sangat diperlukan oleh setiap perusahaan terlebih perusahaan jasa konstruksi seperti PT Amarta Karya (Persero) Bekasi. Namun berdasarkan observasi yang dilakukan peneliti, banyak pegawai yang tidak menunjukkan indikasi perilaku OCB dalam melakukan aktivitas kerjanya. Banyak pegawai yang masih datang terlambat, dan ada beberapa karyawan yang cenderung tidak terlalu memperhatikan lingkungan kerja dan rekan kerjanya. Pegawai tersebut hanya sebatas melaksanakan tanggung jawab yang diberikan oleh organisasi kepadanya

Pembentukan perilaku

OCB dipengaruhi oleh berbagai faktor. Organ dan Ryan menyebutkan bahwa kepuasan kerja memiliki hubungan yang positif dan signifikan dalam pembentukan OCB anggota organisasi (Bharata, et al., 2016). Kepuasan kerja dapat diasumsikan secara logis sebagai faktor utama penentu OCB (Robbin \& Judge, 2013).

Selain itu perubahan yang terjadi terhadap budaya organisasi memiliki pengaruh yang signifikan terhadap perilaku OCB (Bharata, et al., 2016), sedangkan Brahmasari (2008) dalam penelitiannya menemukan bahwa komitmen pegawai memiliki pengaruh yang signifikan terhadap pembentukan OCB karyawan, selain itu Chiaburu, et al., (2011) menjelaskan bahwa kepribadian pegawai lebih baik dalam memprediksi OCB dibandingkan kinerja pegawai tersebut

Berdasarkan penjelasan diatas dapat diketahui bahwa OCB dipengaruhi oleh faktor internal seperti, kepuasan kerja, komitmen pegawai, dan kepribadian, selain itu OCB juga dipengaruhi oleh faktor eksternal yaitu budaya organisasi, kemudian kepribadian berpengaruh terhadap OCB-O (Organizational Citizenship BehaviourOrganization) namun kepribadian tidak berpengaruh terhadap OCB-I (Organizational Citizenship BehaviourIndividual) (Sambung \& Iring, 2014).

Kepribadian merupakan keunikan yang membedakan antara satu individu dengan individu lainnya. Organ berpendapat bahwa perbedaan individu merupakan prediktor yang memainkan peran penting pada seorang karyawan sehingga karyawan tersebut akan menunjukan OCB mereka (Sambung \& Iring, 2014). Kepribadian dianggap menjadi prediktor paling besar diantara variabel lainnya dalam membentuk perilaku OCB dalam diri seseorang karena kepribadian merupakan sesuatu yang melekat pada diri seseorang yang sangat sulit diubah sehingga memiliki hubungan yang lebih stabil dan bertahan terhadap $O C B$. Teori model kepribadian yang digunakan dalam penelitian ini adalah Big Five Personality Model. Robbin dan Judge (2013) mengungkapkan Big Five Model adalah lima dimensi dasar yang mencakup sebagian besar variasi signifikan pada kepribadian manusia. Lima dimensi dasar ini dapat memprediksi dengan baik bagaimana perilaku seseorang dalam kehidupan seharihari.

Berdasarkan uraian diatas, Salah satu faktor yang mempengaruhi perilaku OCB adalah kepribadian individu yang bersangkutan. Sementara di PT Amarta Karya (Persero) perilaku OCB ini hanya ditunjukkan oleh sedikit karyawan. Sehingga penting untuk mengetahui pegawai dengan jenis kepribadian bagaimana yang memiliki 
kemungkinan terbesar untuk memiliki OCB dalam bekerja sebagai dasar pengambilan keputusan untuk mempertahankan pegawai yang ada atau merekrut pegawai baru. disamping itu terdapat adanya fakta yang berbeda yang dite mukan olehberbagai hasil penelitian. Hal tersebut yang menjadi dasar peneliti untuk melakukan penelitian kembali dengan judul yang sama.

\section{KAJIAN TEORI \\ Organizational Citizenship Behaviour $(\mathrm{OCB})$}

Organ mengungkapkan bahwa OCB adalah perilaku sukarela yang dilakukan oleh individu tanpa memikirkan atau mempertimbangkan sistem reward formal yang ada, sehingga dapat meningkatkan produktifitas suatu organisasi (Ehtiyar, 2010), kemudian Brahmasari, (2008) dalam penelitiannya menjelaskan Organizational Citizenship Behavior (OCB) merupakan perilaku yang optional yang artinya bebas untuk dilakukan atau tidak oleh seorang anggota organisasi (Brahmasari, 2008), selain itu dapat dijelaskan bahwa OCB merupakan perilaku kerja yang ditunjukkan oleh karyawan yang dilakukan melebihi perannya secara formal dalam perusahaan.

Berdasarkan definisi diatas dapat dipahami bahwa secara umum Organizational Citizenship Behaviour atau OCB adalah suatu perilaku individual yang bersifat sesuai dengan kehendak hati (discretionary) yang bebas untuk dilakukan atau tidak oleh anggota organisasi yang dapat mendorong terciptanya peningkatan efektivitas dan efisiensi organisasi. Salah satu indikasi dari perilaku OCB adalah karyawan melaksanakan pekerjaan melebihi peran atau tanggung jawab yang sudah dibebankan kepadanya berdasarkan pada kerelaan hatinya dan tidak ada unsur pemaksaan dari pihak manapun.

Sharma \& Jaim, (2014) dalam penelitiannya memberikan penjelasan bahwa pada praktiknya dalam organisasi terdapat dua jenis perilaku OCB yang dapat diukur yaitu OCB yang bersifat indvidu (OCBI) dan OCB yang bersifat organisasional (OCBO). OCBI adalah perilaku individu yang secara langsung memberikan manfaat spesifik bagi individu lain dan manfaat tidak langsung terhadap organisasi. OCBO adalah perilaku yang memberikan manfaat secara umum terhadap organisasi.

Selanjutnya Sharma dan Jain, (2014) pada penelitannya menggunakan 5 dimensi yang terdiri dari dari Alturism, Conscientiousness, Sportmanship, Courtessy, dan Civic Virtue. Kemudian dapat dijelaskan bahwa Alturism merupakan perilaku karyawan dalam menolong rekan kerjanya yang sedang dalam kesulitan baik dalam masalah pekerjaan maupun masalah pribadi. Conscientiousness merupakan perilaku yang ditunjukkan dengan melaksanakan sesuatu melebihi apa yang diharapkan oleh organisasi atau melebihi tanggung jawab yang dibebankan oleh organisasi terhadap pegawai yang bersangkutan. Sportmanship merupakan perilaku toleransi terhadap keadaan-keadaan yang kuarang ideal dalam organisasi dimana karyawan itu bekerja. Courtessy merupakan perilaku menjaga hubungan baik dengan rekan kerjanya untuk menghindari konflik interpersonal dalam organisasi. Dimensi ini merujuk kepada perilaku menghargai dan memperhatikan orang lain. Dan civic virtue merupakan perilaku mengutamakan kepentingan organisasi dan secara sukarela menjalankan fungsi atau perannya dalam organisasi.

\section{Kepribadian}

Definisi kepribadian menurut Gibran adalah himpunan karakteristik, kecenderungan dan temperamen yang relatif stabil yang dibentuk secara nyata oleh faktor keturunan dan faktor sosial, budaya, dan lingkungan serta menentukan sifat umum dan perbedaan dalam pribadi seseorang (Isvandiary \& Susilo, 2014), kemudian 
kepribadian dapat diartikan sebagai total jumlah dari cara-cara yang ditempuh seseorang individu beraksi dan berinteraksi dengan orang-orang lain (Robbin \& Judge, 2013). Kepribadian juga dapat diiuraikan sebagai cara seseorang merespon terhadap masalah, bersifat unik, dinamis, yang merupakan hasil interaksi fisik/genetik, environment, emotional, cognition, serta menunjukan cara individu dalam mengelola (management) waktunya (Sambung \& Iring, 2014).

Berdasarkan pendapat para ahli diatas dapat dipahami bahwa definisi kepribadian secara umum adalah karakteristik dan kecenderungan sifat atau ciri yang dimiliki individu dalam memandang diri sendiri dan berinteraksi dengan orang lain yang dibentuk oleh faktor keturunan dan faktor eksternal seperti lingkungan, social, dan budaya.

Teori mengenai model kepribadian yang digunakan oleh peneliti dalam penelitian ini adalah Big Five Personality model adalah teori mengenai model kepribadian yang ditentukan berdasarkan pada lima faktor dasar yang saling mendasari dan mencakup sebagian besar variasi yang signifikan dalam kepribadian manusia.

Big Five Personality terdiri dari 5 dimensi dasar yang meliputi extraversion, agreeableness, conscientiousness, neuroticsm, dan Openness. Dimensi ekstraversi (extraversion) mengungkapkan tingkat kenyamanan individu dalam menjalin hubungan dengan orang lain. Individu yang memiliki dimensi ini adalah pribadi yang suka hidup berkelompok, tegas, dan mudah bersosialisasi dengan orang lain maupun dengan lingkungan barunya. Dimensi kepribadian agreeableness merujuk pada kepatuhan seorang individu terhadap individu lainnya. Individu yang memiliki model kepribadian ini merupakan pribadi yang senang bekerja sama, ramah, hangat, dan penuh kepercayaan kepada orang lain. Individu dengan dimensi kepribadian conscientiousness adalah orang yang bertanggung jawab terhadap tugasnya, teratur, dapat diandalkan, dan gigih. Dimensi kepribadian Emotional Stability merujuk pada kemampuan seorang individu untuk menahan stress yang dihadapi. Individu dengan karakter stabilitas emosi yang postif akan cenderung tenang dan percaya diri dalam menghadapi suatu masalah, serta juga memiliki pendirian yang teguh. Sementara individu dengan stabilitas emosi yang negatif atau neuroticsm yang tinggi akan cenderung mudah gugup, khawatir, dan depresi dalam menghadapi masalah, serta tidak memiliki pendirian yang teguh. Dimensi kepribadian Openess to Experience mengelompokkan individu berdasarkan lingkup minat dan ketertarikannya terhadap hal-hal baru. Individu yang terbuka akan cenderung kreatif, memiliki keingintahuan yang tinggi, dan sensitive terhadap hal-hal yang berhubungan dengan seni. Sebaliknya individu yang tertutup akan cenderung memiliki sifat konvensional dan merasa nyaman terhadap hal-hal yang telah ada di sekitarnya (Robbin \& Judge, 2013).

\section{Hubungan Big Five Personality Terhadap Pembentukan Organizational Citizenship Behaviour (OCB)}

Berdasarkan penjelasan diatas dapat diketahui bahwa OCB dipengaruhi oleh berbagai faktor yaitu faktor internal dan faktor eksternal. faktor internal seperti, kepuasan kerja, komitmen pegawai, dan kepribadian. Selain itu OCB juga dipengaruhi oleh faktor eksternal yaitu budaya organisasi.

Penelitian yang dilakukan oleh Sambung dan Iring, (2014) menemukan bahwa kepribadian berpengaruh positif dan signifikan terhadap OCB pegawai. Hasil Analisis regresi dalam penelitan Mahdiuon, Ghahramani, \& Sharif, (2010) juga menunjukkan bahwa conscientiousness, agreeableness dan openness memprediksi OCB 
Soepono \& Srimulyani,

Menguji secara langsung dan tidak langsung pengaruh Kepribadian Big Five terhadap kinerja perawat di RS. Santa Clara Madiun dengan OCB sebagai variabel Intervening dan menghasilkan kepribadian Big Five secara signifikan dan positif mempengaruhi kinerja perawat, kepribadian Big Five secara signifikan dan positif mempengaruhi OCB, dan OCB memiliki efek mediasi penuh dalam mempengaruhi kepribadian Big Five.

Penelitian yang telah dilakukan seperti yang telah dijelaskan, menunjukkan adanya perbedaan hasil mengenai hubungan antara dimensi neuroticsm terhadap OCB. Hal tersebut membutuhkan penelitian lebih lanjut untuk mengetahui secara tepat mengenai hubungan antara dimensi neuroticsm terhadap OCB. Namun sebagian besar penelitian sebelumnya menemukan bahwa semua dimensi Big Five Personality memiliki pengaruh yang positif dan signifikan terhadap OCB.

Berdasarkan referensi diatas maka dapat diduga bahwa terdapat hubungan yang signifikan antara dimensi kepribadian Big Five personality terhadap pembentukan Organizational Citizenship Behaviour pegawai. Konsep dalam penelitian ini dapat dilihat pada gambar berikut.

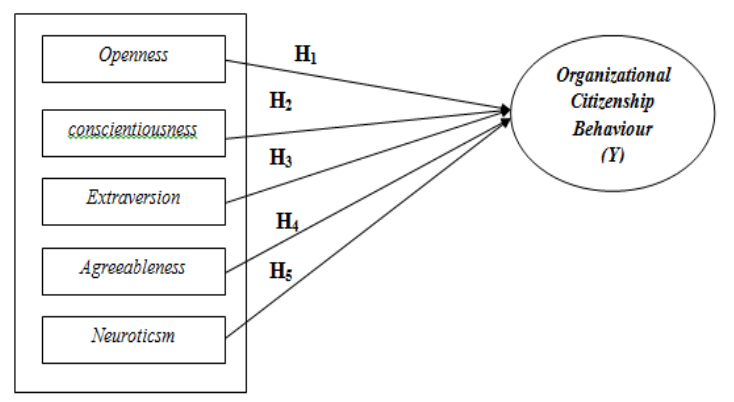

Gambar 1. Konsep yang dikembangkan oleh peneliti

H1: Terdapat hubungan yang signifikan antara dimensi kepribadian Openness terhadap pembentukan OCB pegawai. H2: Terdapat hubungan yang signifikan antara dimensi kepribadian Conscientiousnness terhadap pembentukan
OCB pegawai. H3: Terdapat hubungan yang signifikan antara dimensi kepribadian Extraversion terhadap pembentukan OCB pegawai. H4: Terdapat hubungan yang signifikan antara dimensi kepribadian Agreeableness terhadap pembentukan OCB pegawai. H5 : Terdapat hubungan yang signifikan antara dimensi kepribadian Neuroticsm terhadap pembentukan OCB pegawai.

\section{METODE}

Penelitian ini menggunakan metode kuantitatif, untuk mengetahui hubungan antara kepribadian Big Five terhadap pembentukan OCB menggunakan perhitungan korelasi product moment Pearson dengan bantuan aplikasi SPSS 2.0. Populasi merupakan keseluruhan objek kejadian atau tempat dari keseluruhan yang berada didalam penelitian sedangkan sampel adalah sebagian jumlah dari populasi. Menurut Arikunto (2010) mengungkapkan bahwa jika subjek penelitian kurang dari 100 lebih baik dijadikan seluruhnya menjadi sampel sehingga penelitiannya merupakan populasi. Tetapi jika jumlah subjeknya besar dapat diambil antara $10-15 \%$ atau $15-25 \%$ atau lebih. Hal ini sesuai dengan yang dijelaskan bahwa ukuran sampel yang layak dalam suatu penelitian yaitu antara 30-500 (K., 2016). Dalam penelitian ini yang menjadi populasi adalah seluruh karyawan PT. Amarta Karya (Persero) Bekasi sejumlah 136 orang karyawan tidak termasuk tenaga outsourcing. Maka jumlah sampel dalam penelitian ini adalah $25 \%$ dari jumlah populasi yaitu sebesar 34 orang. Metode pengambilan sampel yang akan digunakan dalam penelitian ini adalah metode Simple Random sampling yaitu penentuan sampel tanpa dikategorisasikan terlebih dahulu, semua populasi memiliki kesempatan yang sama untuk menjadi sampel dalam penelitian. Karyawan yang menjadi sampel dalam penelitian ini adalah karyawan yang berada dalam Biro SDM, 
Sistem, dan Umum (BSSU), Biro Pemasaran dan Tehnik ( BPT), dan Divisi Fabrikasi dan Peralatan ( DFP ) dengan total jumlah karyawan sebanyak 30 orang. Dengan uraian sebagai berikut, BSSU terdiri dari 11 orang pegawai, BPT terdiri dari 13 orang pegawai, dan DFP terdiri dari 10 orang pegawai.

Dari keseluruhan kuesioner yang diberikan kepada setiap responden, 4 diantaranya tidak diberikan kembali kepada peneliti sehingga total jumlah kuesioner yang kembali kepada peneliti sebanyak 30 buah. Sehingga jumlah akhir sampel dalam penelitian ini adalah sebanyak 30 orang karyawan. Penentuan sampel diatas juga berdasarkan akses yang diizinkan oleh perusahaan dan kesediaan karyawan yang berada di tempat kerja karena banyak karyawan yang ditugaskan oleh perusahaan untuk menyelesaikan proyek-proyek konstruksi yang berlokasi jauh dari kantor pusat perusahaan yang berada di Bekasi. Disamping itu semua divisi tersebut merupakan divisi utama yang memiliki peran penting dalam perusahaan.

Teknik pengumpulan data dalam penelitian ini adalah dengan melakukan observasi dan wawancara secara tidak terstruktur terhadap karyawan dan kemudian mendistribusikan sejumlah kuesioner kepada karyawan yang menjadi target responden, didalam kuesioner ini terdapat 2 skala yaitu, Skala Kepribadian (Big Five Personality) dan Skala OCB-C.

Instrumen yang digunakan oleh peneliti untuk mengukur kepribadian sampel adalah menggunakan instrument Big Five Inventory berdasarkan pada teori Big Five Personality Model. Skala Big Five Inventory sudah diadaptasi kedalam bahasa Indonesia lalu dilakukan uji konfirmatori pada Tahun 2004 oleh Bapak Wahyu Widiarso yang merupakan Dosen UGM . Uji konfirmatori disini, merupakan suatu uji yang bertujuan untuk melihat konsistensi konstruk Big Five Personality, skala kepribadian ini berisi 35 pernyataan, dimana 35 butir tersebut disusun oleh 5 dimensi yaitu, Extraversion, Conscientousness, Agreeableness, Neuroticism, dan Openess. Masing-masing dimensi direpresentasikan oleh 7 pertanyaan. Dalam penelitian ini, peneliti melakukan pengukuran skala kepribadian dengan 5 pilihan alternatif jawaban yaitu Sangat Tidak Setuju (STS), Tidak Setuju (Tidak Setuju), Netral (N), Setuju (S), dan Sangat Setuju (S). Validitas dan reliabilitas alat ukur (kuesioner) yang digunakan pada penelitian ini merujuk pada penelitian John dan Srivastava yaitu untuk validitas rata-rata sebesar 0.83 hingga 0.91 dan realibilitas alat ukur ini adalah sebesar antara 0.75 hingga 0.80 (Nasyroh \& Wikansari, 2017).

Instrumen yang digunakan untuk mengukur OCB dalam penelitian ini adalah OCB-C (Organizational Citizenship Behaviour Checklist) 20 item (terdiri dari OCBO dan OCBP) sebagai skala akhir yang dirancang dan direkomendasikan untuk digunakan (S, et al., 2012). OCB-C yang tersedia dalam bahasa inggris diadaptasi ke dalam bahasa Indonesia dengan metode back translate yaitu dengan menterjemahkan setiap butir pernyataan ke dalam bahasa Indonesia, lalu menterjemahkan hasil terjemahan bahasa Indonesia ke dalam bahasa inggris kembali. OCB-C menggunakan 5-point skala frekuensi yaitu Tidak pernah, Pernah (Dilakukan sekali atau dua kali), Jarang (Dilakukan sekali atau dua kali dalam sebulan), Sering (Dilakukan sekali atau dua kali dalam seminggu), dan Selalu (Dilakukan Setiap hari) dengan skor setiap jawaban adalah sebagai berikut

Jenis validitas yang diigunakan untuk menentukan validitas alat ukur OCB-C ini adalah validitas Isi. Gregory mengngkapkan Validitas Isi (Content Validity) adalah Validitas yang menjelaskan sejauh mana isi tes mewakili atribut yang hendak diukur. Cara menentukan validitas isi alat ukur dapat dilakukan dengan menggunakan pendapat suatu 'panel' yang terdiri dari ahli-ahli dalam bidang yang sesuai dengan atribut 
yang ingin diukur validitasnya (Djali \& Pudji, 2007). Berikut proses pengujian validitas content dari instrumen OCB-C yang digunakan dalam penelitian ini.

20 item OCB-C yang menjadi alat ukur merupakan hasil dari diskusi yang dilakukan oleh para subjek ahli. Item-item pernyataan didasarkan pada 214 peristiwa penting yang disampaikan oleh 38 subjek ahli (SMEs) yang merupakan mahasiswa pasca sarjana dan alumni Masters of Science in Human Resources (MSHR) dan program MBA yang memiliki pengalaman bekerja. Subjek diberikan 42 item dan diminta untuk mengisi pernyataan tersebut dengan menyebutkan berapa kali mereka melakukan hal-hal yang ada dalam 42 item OCB-C tersebut.

Hal tersebut dilakukan untuk menghilangkan redundansi dan ide-ide yang tidak dapat digunakan. Berikutnya item diklasifikasikan ke dalam kategori OCBO dan OCBP oleh 22 subjek ahli (SMEs) yang terdiri dari siswa dari MSHR, MBA, dan industri / organisasi program doktor. Skala OCBO akhir memiliki 15 item, dan skala OCBP akhir memiliki 14 item. Enam item dari versi 42-item dieliminasi dan diberikan skala tambahan sehingga dihasilkan versi 36-item. Isi dari skala OCBO tetap sama, tapi skala OCBP memiliki 8 item. Selanjutnya skala dikembangkan kembali menjadi total 20 item (terdiri dari OCBO dan OCBP) sebagai skala akhir yang dianggap tepat untuk digunakan secara umum (S, Spector, Goh, Bruursema, \& Kessler, 2012).

Reliabilitas OCB-C memiliki nilai Cronbach's Alpha sebesar 0,770 > 0,60 yang artinya semua pernyataan dalam skala OCBC reliabel.

\section{HASIL DAN PEMBAHASAN Hasil}

Responden pada penelitian ini adalah karyawan PT. Amarta Karya (persero) Bekasi yang meliputi karyawan dalam BSSU, BPT, dan DFP dengan total jumlah responden sebanyak 30 orang karyawan. Karyawan yang menjadi responden yaitu terdiri 22 Pria $(73,33 \%)$ dan 8 wanita $(26,67 \%)$.

Berdasarkan usia karyawan yang menjadi responden terdiri dari 17 orang berusia $20-35$ tahun $(56,67 \%), 5$ orang berusia $35-45(16,67 \%)$, dan 8 orang yang berusia lebih dari 45 tahun atau sebesar $(26,66 \%)$. Berdasarkan tingkat pendidikan, karyawan yang menjadi responden terdiri dari 6 orang dengan pendidikan terakhir SLTA (20\%), 5 orang dengan pendidikan terakhir Diploma $3(16,67 \%)$, dan 19 orang dengan pendidikan terakhir S1 $(63,33 \%)$. Berdasarkan lama bekerja, karyawan yang menjadi responden terdiri dari 1 orang dengan lama bekerja kurang dari 1 tahun $(3,33 \%), 12$ orang dengan lama bekerja 1-5 tahun (40\%), 4 orang dengan lama bekerja 6-10 tahun $(13,33 \%), 5$ orang dengan lama bekerja $11-15$ tahun $(16,67 \%)$, dan 8 orang dengan lama bekerja lebih dari 15 tahun $(26,67 \%)$.

Data dari 30 orang karyawan PT. Amarta Karya (persero) Bekasi yang menjadi responden yaitu memiliki skor kepribadian tertinggi sebesar 124, skor terendah 94, skor rata-rata 107,13 , dan skor standar deviasi 8,131. Sedangkan untuk Organizational Citizenship Behaviour (OCB) yaitu skor tertinggi sebesar 76, skor terendah 38 , skor rata-rata 58,73, dan standar deviasi sebesar 10,670.

Sementara hasil analisis deskriptif data untuk masing-masing dimensi Big Five Personality adalah sebagai berikut. Untuk dimensi Openness, skor tertinggi sebesar 30, skor terendah sebesar 17 , nilai rata-rata sebesar 21,43, dan nilai standar deviasi sebesar 2,788. Untuk dimensi Conscientiousness, skor tertinggi sebesar 27, skor terendah sebesar 20, nilai rata-rata sebesar 23,17, dan nilai standar deviasi sebesar 1,984. Untuk dimensi Extraversion, skor tertinggi sebesar 25, skor terendah sebesar 18 , nilai rata-rata sebesar 21,73 , dan 
nilai standar deviasi sebesar 1,837. Untuk dimensi Agreeableness, skor tertinggi sebesar 25, skor terendah sebesar 16 , nilai rata-rata sebesar 21,10, dan nilai standar deviasi sebesar 2,325. Dan untuk dimensi Neuroticsm, skor tertinggi sebesar 27, skor terendah sebesar 14 , nilai rata-rata sebesar 20,03, dan nilai standar deviasi sebesar 3,296 .
Kategorisasi nilai kepribadian ini adalah klasifikasi tingkat kepribadian responden berdasarkan jawaban dari kuesioner. Kategorisasi ini terbagi menjadi tiga yaitu Tinggi, Sedang, dan Rendah dengan berdasarkan kriteria sebagai berikut.

Tabel 1. Kategorisasi Kepribadian

\begin{tabular}{cccccc}
\hline & Mean & SD & Tinggi & Sedang & Rendah \\
\cline { 4 - 6 } & & & $X \geq$ Mean + SD & Mean - SD $\leq X \leq$ Mean + SD & $X \leq$ Mean - SD \\
\hline Openness & 21,43 & 2,788 & $X \geq 24,218$ & $18,642 \leq X \leq 24,218$ & $X \leq 18,642$ \\
Conscientiousness & 23,17 & 1,984 & $X \geq 25,154$ & $21,186 \leq X \leq 25,154$ & $X \leq 21,186$ \\
Extraversion & 21,73 & 1,837 & $X \geq 23,567$ & $19,893 \leq X \leq 23,567$ & $X \leq 19,893$ \\
Agreeableness & 21,10 & 2,325 & $X \geq 23,425$ & $18,775 \leq X \leq 23,425$ & $X \leq 18,775$ \\
Neuroticsm & 20,03 & 3,296 & $X \geq 23,326$ & $16,734 \leq X \leq 23,326$ & $X \leq 16,734$ \\
\hline
\end{tabular}

Berdasarkan tabel diatas penentuan tingkat kepribadian masing-masing dimensi adalah sebagai berikut. Openness akan memiliki kriteria yang tinggi apabila nilai lebih besar dari 24,218, sedang yaitu antara 18,642 hingga 24,218, dan rendah kurang dari 17,848. Conscientiousness akan memiliki kriteria yang tinggi apabila nilai lebih besar dari 25,154, sedang yaitu antara 21,186 hingga 25,154, dan rendah kurang dari 21,186. Extraversion akan memiliki kriteria yang tinggi apabila nilai lebih besar dari 23,567 , sedang yaitu antara 19,893 hingga 23,567, dan rendah kurang dari 19,893. Agreeableness akan memiliki kriteria yang tinggi apabila nilai lebih besar dari 23,425, sedang yaitu antara 18,775 hingga 23,425 , dan rendah kurang dari 18,775. Dan

Neuroticsm akan memiliki kriteria yang tinggi apabila nilai lebih besar dari 23,326, sedang yaitu antara 16,734 hingga 23,326, rendah kurang dari 16,734. Berdasarkan lima dimensi kepribadian, kriteria nilai tertinggi ada pada dimensi Conscientiousness yaitu sebesar 25,154 sedangkan terendah ada pada dimensi Neuroticsm yaitu sebesar 16,734

Distribusi nilai responden merupakan tingkatan atas masing-masing dimensi kepribadian yang dimiliki oleh setiap responden. Distribusi nilai kepribadian responden untuk setiap dimensi kepribadian dapat terlihat pada tabel dibawah ini

Tabel 2. Distribusi Nilai Kepribadian

\begin{tabular}{|c|c|c|c|c|c|c|c|c|c|c|}
\hline \multirow[t]{2}{*}{ Nilai } & \multicolumn{2}{|c|}{ Extraversion } & \multicolumn{2}{|c|}{ Openess } & \multicolumn{2}{|c|}{ Conscientiousness } & \multicolumn{2}{|c|}{ Agreeableness } & \multicolumn{2}{|c|}{ Neuriticism } \\
\hline & $\Sigma$ & $\%$ & $\Sigma$ & $\%$ & $\sum$ & $\%$ & $\sum$ & $\%$ & $\sum$ & $\%$ \\
\hline Tinggi & 6 & $20 \%$ & 2 & $6,67 \%$ & 4 & $13,33 \%$ & 6 & $20 \%$ & 7 & $23,33 \%$ \\
\hline Sedang & 20 & $66,67 \%$ & 27 & $90 \%$ & 18 & $60 \%$ & 20 & $66,67 \%$ & 20 & $66,67 \%$ \\
\hline Rendah & 4 & $13,33 \%$ & 1 & $3,33 \%$ & 8 & $26,67 \%$ & 4 & $13,33 \%$ & 3 & $10 \%$ \\
\hline
\end{tabular}

Berdasarkan tabel diatas dapat terlihat bahwa responden yang memiliki kepribadian Extraversion dengan tingkat yang rendah sebanyak 4 orang $(13,33 \%)$, tingkat sedang sebanyak 20 orang $(66,67 \%)$, dan tingkat yang tinggi sebanyak 6 orang (20\%). Untuk Openness dengan tingkat yang rendah sebanyak 1 orang $(3,33 \%)$, tingkat sedang 
sebanyak 27 orang (90\%), dan tingkat yang tinggi sebanyak 2 orang $(6,67 \%)$. Conscientiousness dengan tingkat yang rendah sebanyak 8 orang $(26,67 \%)$, tingkat sedang sebanyak 18 orang $(60 \%)$, dan tingkat yang tinggi sebanyak 4 orang $(13,33 \%)$. Agreeableness dengan tingkat yang rendah sebanyak 4 orang $(13,33 \%)$, tingkat sedang sebanyak 20 orang $(66,67 \%)$, dan tingkat yang tinggi sebanyak 6 orang (20\%). Neuroticsm dengan tingkat yang rendah sebanyak 3 orang $(10 \%)$, tingkat sedang sebanyak 20 orang $(66,67 \%)$, dan tingkat yang tinggi sebanyak 3 orang (10\%).

Tabel 3. Distribusi Nilai OCB

\begin{tabular}{lcc}
\hline Tingkatan & Jumlah & Presentase \\
\hline Tinggi & 5 & $16,66 \%$ \\
Sedang & 20 & $66,67 \%$ \\
Rendah & 5 & $16,66 \%$ \\
Jumlah & 30 & $100 \%$ \\
\hline
\end{tabular}

Penggolongan tingkatan OCB ini didasarkan pada jawaban responden yang kemudian diolah oleh peneliti dengan melakukan analisis deskriptif. Berdasarkan tabel diatas dapat terlihat bahwa responden yang memiliki Organizational Citizenship Behaviour (OCB) dengan tingkat yang rendah sebanyak 5 orang atau sebesar 16,66 $\%$, tingkat sedang sebanyak 20 orang atau sebesar $66,67 \%$, dan tingkat yang tinggi sebanyak 5 orang atau sebesar 16,66\%.

Tabel 4. Hasil Uji Korelasi

\begin{tabular}{lcc}
\hline \multicolumn{1}{c}{ Variabel } & \multicolumn{2}{c}{ Kinerja } \\
\cline { 2 - 3 } & $\begin{array}{l}\text { Pearson } \\
\text { Correkation }\end{array}$ & $\begin{array}{l}\text { Sig. (2- } \\
\text { tailed) }\end{array}$ \\
\hline Openness & $0,377^{*}$ & 0,040 \\
Conscientiousness & $-0,157$ & 0,406 \\
Extraversion & 0,053 & 0,783 \\
Agreeableness & $-0,198$ & 0,295 \\
Neuroticsm & $-0,060$ & 0,755 \\
\hline *. Correlation is significant at the 0.05 level (2- \\
tailed).
\end{tabular}

Nilai korelasi Pearson untuk dimensi Openness terhadap pembentukan OCB sebesar 0,377 dengan signifikansi $(\mathrm{p})=$ $0,040<0,05$. Maka dapat diketahui bahwa terdapat hubungan yang signifikan antara kepribadian Openness dengan OCB karyawan. Dengan demikian hipotesis alternatif $\mathrm{H} 1$ yang menyatakan ada hubungan yang signifikan antara Openness dengan OCB diterima. Selain itu tidak hanya signifikan namun juga terdapat hubungan yang positif antara dimensi Openness dengan OCB pegawai pada PT Amarta Karya (persero) Bekasi

Nilai korelasi Pearson untuk dimensi Conscientiousness terhadap pembentukan OCB sebesar -0,157 dengan signifikansi (p) $=0,406>0,05$. Maka dapat diketahui bahwa tidak terdapat hubungan yang signifikan antara kepribadian Conscientiousness dengan OCB pegawai pada PT Amarta Karya (persero) Bekasi. Dengan demikian hipotesis alternatif $\mathrm{H} 2$ yang menyatakan ada hubungan yang signifikan antara Conscientiousness dengan OCB ditolak.

Nilai korelasi Pearson untuk dimensi Extraversion terhadap pembentukan OCB sebesar 0,053 dengan signifikansi $(\mathrm{p})=$ $0,783>0,05$. Maka dapat diketahui bahwa tidak terdapat hubungan yang signifikan antara kepribadian Extraversion dengan OCB pegawai pada PT Amarta Karya (persero) Bekasi. Dengan demikian hipotesis alternatif $\mathrm{H} 3$ yang menyatakan ada hubungan yang signifikan antara Extraversion dengan OCB ditolak.

Nilai korelasi Pearson untuk dimensi Agreeableness terhadap pembentukan OCB sebesar $-0,198$ dengan signifikansi $(\mathrm{p})=$ $0,295>0,05$. Maka dapat diketahui bahwa tidak terdapat hubungan yang signifikan antara kepribadian Agreeableness dengan OCB pegawai pada PT Amarta Karya (persero) Bekasi. Dengan demikian hipotesis alternatif $\mathrm{H} 4$ yang menyatakan ada hubungan yang signifikan antara Agreeableness dengan OCB ditolak. 
Nilai korelasi Pearson untuk dimensi Neuroticsm terhadap pembentukan OCB sebesar -0,060 dengan signifikansi $(\mathrm{p})=$ $0,755>0,05$. Maka dapat diketahui bahwa tidak terdapat hubungan yang signifikan antara kepribadian Neuroticsm dengan OCB pegawai pada PT Amarta Karya (persero) Bekasi. Dengan demikian hipotesis alternatif H5 yang menyatakan ada hubungan yang signifikan antara Neuroticsm dengan OCB ditolak.

\section{Pembahasan}

Hasil analisis data menunjukkan hipotesis $\mathrm{H} 1$ yang menyatakan terdapat hubungan yang signifikan antara Openness dengan OCB diterima. Hasil penelitian ini konsisten dengan penelitian Chiaburu, et al., (2011) yang berjudul The Five-Faktor Model of Personality Traits and Organizational Citizenship Behaviors: A Meta-Analysis menyebutkan bahwa OCB memiliki dua kriteria yaitu prososial (diarahkan ke individu atau organisasi; OCB-I dan OCBO) dan proaktif (atau berubah arah; OCB$\mathrm{CH})$.

OCB dalam bentuk prososial (atau afiliatif) diarahkan ke organisasi (OCB-O) dan terhadap individu lain (OCB-I) dan dapat dianggap menjaga konteks sosial di tempat kerja. Sebaliknya, bentuk proaktif yaitu orientasi untuk berubah dan meningkatkan aspek-aspek dalam organisasi dengan membawa perubahan yang positif (change-oriented citizenship; $\mathrm{OCB}-\mathrm{CH}$ ), (Chiaburu, et al., 2011).

Seppala, et al., (2012) menjelaskan dalam penelitiannya bahwa Change-oriented OCB adalah upaya menerapkan perubahan yang berhubungan dengan metode kerja, kebijakan, dan prosedur kerja untuk memperbaiki situasi dan kinerja. Terdapat hubungan antara Agreeableness dengan OCB-I dan Conscientiousness dengan OCBO. Sementara Openness dan Extraversion dengan (OCB-CH) dan menyebutkan bahwa dimensi Openness adalah yang terbaik atau terbaik kedua sebagai prediktor untuk ketiga hasil OCB (OCB-I, OCB-O, dan OCB-CH), Meskipun Conscientiousness memprediksi OCB-O dan Agreeableness Memprediksi OCB-I, kedua dimensi ini tidak memprediksi hasilnya lebih baik daripada Openness, sehingga gagal mendukung harapan untuk Conscientiousness Dan Agreeableness sebagai prediktor terbaik OCB-O Dan OCBI (Chiaburu, et al., 2011).

Individu dengan openness yang tinggi akan cenderung lebih kreatif dalam bidang sains dan seni. Kreatifitas merupakan hal yang penting dalam memimpin suatu organisasi. Individu ini juga menyukai perubahan dan hal-hal baru. Mereka akan lebih mudah beradaptasi dalam perubahan dan hal-hal baru yang diterapkan. (Robbin \& Judge, 2013). Soepono \& Srimulyani, (2015) pada penelitiannya menjelaskan individu openness dengan skor yang rendah memiliki sifat yang konvensional, berorientasi pada adat yang berlaku, memiliki pandangan sempit, tidak artistik, tidak analitis, dan merasa nyaman dengan hal-hal yang telah ada.

Individu dengan kepribadian openness akan cenderung memiliki minat yang lebih terhadap hal-hal baru dalam bidang pekerjaannya. Sehingga seseorang dengan dimensi ini akan dapat menunjukkan salah satu perilaku OCB yaitu civic virtue yaitu perilaku yang mendukung profesionalisme dan fungsi social dari sebuah organisasi dengan mempertimbangkan tujuan utama organisasi. Individu ini akan mudah untuk menerima setiap perubahan yang terjadi dalam organisasi serta memberikan inisiatif rekomendasi-rekomendasi terbaru dalam organisasi mengenai sistem kerja organisasi.

Nilai korelasi Pearson untuk dimensi Conscientiousness terhadap pembentukan OCB sebesar -0,157 dengan signifikansi (p) $=0,406>0,05$. Maka dapat diketahui bahwa tidak terdapat hubungan yang signifikan antara kepribadian Conscientiousness dengan OCB karyawan. Dengan demikian 
hipotesis $\mathrm{H} 2$ yang menyatakan terdapat hubungan yang signifikan antara dimensi kepribadian conscientiousness terhadap OCB ditolak. Dimensi kepribadian conscientiousness memiliki hubungan yang negatif terhadap pembentukan OCB pegawai pada PT Amarta Karya (persero) Bekasi.

Individu dengan kepribadan conscientiousness adalah orang yang dapat diandalkan, sangat teliti, bertanggung jawab, terorganisir, dan gigih. Sementara orang yang mudah terganggu dan tidak terorganisir menunjukkan bahwa mereka memiliki skor yang rendah untuk kepribadian conscientiousness (Robbin \& Judge, 2013). Individu conscientiousness adalah pribadi yang terorganisir, disiplin, dan ambisius sehingga tidak mentolerir kesalahan ataupun keadaan-keadaan yang kurang ideal dalam organisasi.

Peneliti berpandangan bahwa hal tersebut yang membuat dimensi kepribadian conscientiousness memiliki hubungan yang negatif terhadap pembentukan OCB karena salah satu indikasi perilaku OCB adalah mentolerir keadaan-keadaan yang kurang ideal (sportmanship), senang bekerja sama dan menolong rekan kerja yang sedang kesulitan ataupun berbuat kesalahan ketika melaksanakan pekerjaan. Disamping itu individu conscientiousness cenderung lebih menyukai bekerja secara perorangan dibandingkan bekerja sama dalam tim dan hal ini dapat menghambat pembentukan OCB individu.

Hasil analisis data diatas juga menunjukkan terdapat hubungan positif yang tidak signifikan (sangat rendah) antara kepribadian Extraversion dengan OCB karyawan. Dengan demikian hipotesis H3 yang menyatakan terdapat hubungan yang signifikan antara Extraversion dengan OCB ditolak.

Individu dengan kepribadian extraversion memiliki kenyamanan dalam menjalin hubungan dengan sesama suka berteman, asertif, dan mudah bergaul.
Sementara individu dengan skor extraversion yang rendah adalah individu dengan kepribadian introvert yang memiliki sifat yang berbanding terbalik yakni, pendiam dan pemalu. (Robbin \& Judge, 2013). Individu dengan dimensi extraversion yang tinggi cenderung aktif, mudah bersosialisasi, suka berbicara, berorientasi pada hubungan antar sesama manusia (social relation oriented), cenderung optimistis, periang, dan sikap afektif (penyayang). Individu ini akan mudah bekerja dalam tim. Faktor sosial dan kerja sama juga merupakan hal yang penting yang dapat memberikan pengaruh dalam peningkatan OCB individu. Individu dengan kepribadian Extraversion juga cenderung aktif. Kepribadian extraversion merupakan salah satu predictor OCB Pro Aktif atau OCB-CH (Organizational Citizenship BehaviourChange Oriented) (Chiaburu, et al., 2011). Hasil penelitian menunjukkan bahwa ketiga dimensi kepribadian lainnya yaitu neuroticsm, agreeableness, dan conscientiousness memiliki hubungan yang negatif terhadap pembentukan OCB pegawai PT Amarta Karya (persero) Bekasi. Hal ini menunjukkan ketiga dimensi kepribadian tersebut bukan merupakan predictor OCB pegawai pada PT Amarta Karya (persero) Bekasi bahkan memiliki hubungan yang berbanding terbalik dengan pembentukan OCB Pegawai PT Amarta Karya (persero) Bekasi.

Nilai korelasi Pearson untuk dimensi Agreeableness terhadap pembentukan OCB sebesar $-0,198$ dengan signifikansi $(\mathrm{p})=$ $0,295>0,05$. Maka dapat diketahui bahwa tidak terdapat hubungan yang signifikan antara kepribadian Agreeableness dengan OCB karyawan. hipotesis $\mathrm{H} 4$ yang menyatakan terdapat hubungan yang signifikan antara Agreeableness dengan OCB ditolak.

Hasil penelitian ini sangat berbeda dengan penelitan Sambung dan Iring (2014), Mahdiuon, et al., (2010) dan Soeponon \& 
Srimulyani, (2015) yang menunjukkan bahwa dimensi kepribadian agreeableness memiliki hubungan yang positif dan signifikan baik terhadap OCB. Individu agreeableness adalah individu yang berhati lembut dan mudah percaya terhadap seseorang, hal ini membuat individu agreeableness akan cenderung mengalah terhadap individu lain. Peneliti berpandangan bahwa sifat mengalah ini dapat menghambat individu dalam melakukan perubahan dan peningkatan dalam hidupnya karena lebih mendahulukan kepentingan orang lain dibandingkan kepentingan dan minat pribadi. Hal ini yang membuat dimensi kepribadian agreeableness memiliki hubungan negatif dengan OCB change-oriented (OCB-CH) yaitu OCB yang berorientasi pada perubahan pada pegawai PT Amarta Karya (persero) Bekasi.

Nilai korelasi Pearson untuk dimensi Neuroticsm terhadap pembentukan OCB sebesar $-0,060$ dengan signifikansi $(\mathrm{p})=$ $0,755>0,05$. Maka dapat diketahui bahwa tidak terdapat hubungan yang signifikan antara kepribadian Neuroticsm dengan OCB karyawan. Dengan demikian hipotesis H5 yang menyatakan terdapat hubungan yang signifikan antara Neuroticsm dengan OCB ditolak.

Hasil penelitian ini konsisten dengan hasil penelitian Mahdiuon, et al., (2010) yang menemukan bahwa hanya dimensi consciousness, agreeableness dan openness yang menjadi predictor OCB . Adanya hubungan yang negatif antara dimensi kepribadian neuroticsm dengan OCB mengindikasikan bahwa individu yang memiliki emosi yang tidak stabil akan cenderung sering mengeluh dengan keadaankeadaan yang kurang ideal dalam organisasi (sportsmanship) dan hal ini dapat menciptakan lingkungan kerja yang tidak kondusif. Disamping itu individu neuroticsm akan lebih mudah marah sehingga tidak dapat menjalin hubungan yang baik dengan rekan kerjanya. Sementara salah satu indikasi adanya perilaku OCB yang dimiliki oleh individu yaitu menjaga hubungan baik dengan sesama rekan kerja (courtesy).

\section{SIMPULAN}

Nilai korelasi Pearson untuk dimensi Openness terhadap pembentukan OCB sebesar 0,377 dengan signifikansi $(\mathrm{p})=$ $0,040<0,05$. Maka dapat diketahui bahwa terdapat hubungan yang signifikan antara kepribadian Openness dengan OCB karyawan. Individu dengan kepribadian openness akan cenderung memiliki minat yang lebih terhadap hal-hal baru dalam bidang pekerjaannya. Selain itu dimensi openness menjadi prediktor terbaik untuk pembentukn OCB-CH. Karyawan dengan jenis kepribadian openness akan memiliki kemungkinan yang besar untuk menunjukkan perilaku OCB-CH. Individu ini akan mudah untuk menerima setiap perubahan yang terjadi dalam organisasi serta memberikan inisiatif rekomendasirekomendasi terbaru dalam organisasi mengenai sistem kerja organisasi. Hal tersebut akan sangat menguntungkan perusahaan untuk menahadapi perubahanperubahan dalam dunia industri.

\section{REFERENSI}

Arikunto, S. (2010). Prosedur Penelitian : Suatu Pendekatan Praktis. Jakarta: PT Rineka Cipta.

Bharata, Zunaidah, \& Diah, M. Y. (2016). Pengaruh Kepuasan Kerja dan Budaya Organisasi Terhadap Organizational Citizenship Behaviour (OCB) di PT Pupuk Sriwidjadja Palembang (Kasus di Divisi Tekhnologi). Manajemen dan Bisnis Sriwijaya, 257-276.

Brahmasari, I. A. (2008). Pengaruh Variabel Budaya Organisasi, Komitmen, dan Kepuasan Kerja Terhadap Organizational Citizenship Behaviour Pegawai. Jurnal 
Akuntansi, Manajemen, dan Sektor Publik (JAMBSP), 269-290.

Chiaburu, D. S., Oh, I. S., Berry, C. M., Lie, N., \& Gardner, R. G. (2011). The Five Faktor Model of Personality Traits and Organizational Citizenship Behaviour: A Meta-Analysis. Journal of Applied Psychology, 1140-1166.

Djali, \& Pudji, M. (2007). Pengukuran dalam Bidang Pendidikan. Jakarta: Program Pasca Sarjana Universitas Negeri Jakarta.

Ehtiyar, V. R., Alan, A. A., \& Ömüriş, E. (2010). The role of organizational citizenship behavior (OCB) on university students' academic success. Tourism and Hospitality Management, 16, 47-61.

Isvandiary, A., \& Susilo, A. (2014). Pengaruh Kepribadian dan Disiplin Kerja Terhadap Kinerja Karyawan Dinas Luar Asuransi Jiwa Bersama Bumi Putera 1912 Cabang Dieng. Jibeka.

K., F. S. (2016). Metodologi Penelitian Farmasi Komunitas dan Eksperimental . Yogyakarta: Deepublish.

Mahdiuon, R., Ghahramani, M., \& Sharif, A. R. (2010). Explanation of organizational citizenship behavior with personality. Procedia Social and Behavioral Sciences, 178-184.

Nasyroh, M., \& Wikansari, R. (2017). Hubungan Antara Kepribadian (Big Five Personality) dengan Kinerja Karyawan. Jurnal Ecopsy, 10-16.

Pratiwi, I. (2013). Analisis Pengaruh Budaya Organisasi dan Keadilan Organisasi Terhadap Organizational Citizenship Behaviour dengan Komitmen Organisasional sebagai variabel Intervening. Semarang: Universitas Diponegoro.
Robbin, S. P., \& Judge, T. (2013). Organizational Behaviour. USA: PEARSON.

S, F., Spector, P., Goh, A., Bruursema, K., \& Kessler, S. (2012). The Deviant Citizen :Measuring Potential Positive Relation between counterproductive work behaviour and organizational citizenship behaviour. Journal of Occupational and Organizational Psychology, 85, 199-220.

Sambung, R., \& Iring. (2014). Pengaruh Kepribadian Terhadap Organizational Citizenship Behaviour dengan Komitmen Organizational sebagai Variabel Intervening. Manajemen dan Akuntansi, 1-16.

Sari, M. K., \& Hajriani, I. (2015). Pengaruh Karakteristik Budaya Organisasi Terhadap Organizational Citizenship Behaviour. Journal of Economic and Economic Education, 229.

Seppala, T., Lipponen, J., Bardi, A., \& Pirttil“", a.-B. A.-M. (2012). Change Oriented-Organizational Citizenship Behaviour : An Interactive Product of Openness to change values,work unit identification, and sense of power. Journal of Occupational and organizational Psychology, 136-155.

Sharma, V., \& Jain, S. (2014). A Scale for Measuring Organizational Citizenship Behavior in Manufacturing Sector. Pacific Business Review International, 5762.

Soepono, D. N., \& Srimulyani, V. A. (2015). Analisis Pengaruh The Big Five Personality Terhadap Organizational Citizenship Behaviour (OCB) dan Kinerja Perawat di RS Santa Clara Madiun. Jurnal Manajemen Indonesia, 51-64. 